\title{
Thomsen's type myotonia congenita with short-term disability phenomenon
}

\author{
Geçici zaaf fenomenli Thomsen tipi miyotonia konjenita olgusu
}

Lütfi Özel, Recep Demir, Gökhan Özdemir, Ayfer Ertekin, Hızır Ulvi

Atatürk Üniversitesi, Tıp Fakültesi, Nöroloji ABD, Erzurum

\begin{abstract}
Myotonia congenita is a muscle ion channel disorder of non-progressive type, characterized by myotonia and muscle hypertrophy. It has autosomal dominant (Thomsen's type) and recessive (Becker's type) forms. Since it is not easy to differentiate these two forms, differentiation is mainly carried out using the heritage according to the family tree method. A 21-year-old-male was admitted to our outpatient clinic with a complaint of dropping objects from his hand. On physical examination the patient had an athletic appearance with generalized stiffness of the muscles. No atrophy or muscle weakness was present. Deep tendon reflexes were normal. Action myotonia and percussion myotonia were determined. Similar complaints were present in his father and brother. There was no intermarriage between his father and mother. Myotonic releases were detected in electromyography (EMG). Since the same disease was present in his father and brother, a family tree of the patient was established, and accordingly the disease was diagnosed as Thomsen's type Myotonia Congenita. The patient was enrolled into a physiotherapy program. The aim of this study was to point out that although the short-term disability phenomenon is usually seen in Becker's type Myotonia Congenita, it can rarely be observed in Thomsen's type as well.
\end{abstract}

Pam Tıp Derg 2014;7(2):163-166

Key words: Myotonia Congenita, Thomsen's type, short-term disability

\section{Özet}

Miyotonia konjenita kas iyon kanalı hastalıklarından, ilerleyici olmayan, miyotoni ve kas hipertrofisi ile karakterize bir hastalıktır. Otozomal dominant (Thomsen tipi) ve resesif (Becker tipi) formları vardır. Resesif ve dominant miyotonia konjenitayı birbirinden ayırmak her zaman kolay değildir. Ayırım başlıca aile ağacında resesif veya dominant geçişe göre yapılır. Yirmi bir yaşında erkek hasta elinde tuttuğu eşyaları düşürme şikayetiyle polikliniğimize başvurdu. Atletik görünümlü olan hastanın muayenesinde tüm vücut kaslarında genel bir sertlik tespit edildi. Atrofi ve kas güçsüzlüğü yoktu. Derin tendon refleksleri canlıydı. Aksiyon miyotonisi ve perküsyon miyotonisi tespit edildi. Abisinde ve babasında benzeri şikayetler mevcuttu. Anne-baba arasında akraba evliliği yoktu. Laboratuvar incelemeleri normal olarak saptandı. Telekardiyografi, elektrokardiyografi ve ekokardiyografi bulguları normaldi. Elektromyelografide (EMG) miyotonik boşalımlar tespit edildi. Babasında ve abisinde de aynı hastalık mevcut olduğu için hastaya soyağacı çıkarılarak Thomsen tipi Miyotonia Konjenita tanısı konuldu. Hasta fizik tedavi programına alındı. Biz geçici zaaf fenomeni genellikle Becker tipini düşündürse de nadir olarak da Thomsen tipi Miyotonia Konjenitada görülebileceğine dikkat çekmek istedik.

Pam Med J 2014;7(2):163-166

Anahtar sözcükler: Miyotoni Konjenita, Thomsen tipi, geçici zaaf

\section{Introduction}

After voluntary movement or stimulus is terminated, the continuation of the active contraction of a muscle, or the loss of relaxation ability of a muscle is called myotonia [1,2]. Myotonia congenita is the most frequent muscle ion channel disorder characterized by non-progressive type myotonia and muscle hypertrophy, which has no effect on the duration of life $[2,3]$. It has autosomal dominant (Thomsen's type) and recessive (Becker's type) forms [4]. Both forms are defined as channelopathies and include impaired chlorine channels transport. Point mutations on the skeletal muscle chlorine channel gene carried on the $7^{\text {th }}$ chromosome $(7 q 35)$ are responsible for the dominant and recessive forms. If the mutation cannot be determined by genetic

Recep Demir

Yazışma Adresi: Atatürk Üniversitesi, Tıp Fakültesi, Nöroloji ABD, Erzurum

e-mail: recep75@yahoo.com

Gönderilme tarihi: 28.08.2013

Kabul tarihi: 20.02.2014 
testing, the recessive and dominant type differentiation may be performed by using the family tree method [2]. It is not always easy to differentiate between the recessive and dominant types of myotonia congenita. Late onset of the symptoms, ascending progression type, short-term disability phenomenon and severity of myotonia mainly suggest Becker's type, although the opposite may rarely be observed. Differentiation is mainly performed considering the heritage type; dominant or recessive. A specific phenomenon called "short-term disability" is observed in many patients. According to this phenomenon; the first contraction during movement is normal, whereas during the second movement, strength of the muscle suddenly decreases, and this weakness lasts for a few more contractions, then it progressively improves and turns to normal [2]. Herein, a 21-year old-male with Thomsen's type myotonia and short-term disability phenomenon is presented.

\section{Case report}

A 21-year-old-male patient was admitted our outpatient clinic with the complaint of dropping objects from his hands. Stiffness in his muscles was first recognized when he was about 4 or 5 years old. The patient was $1.53 \mathrm{~cm}$ tall and weighed $54 \mathrm{~kg}$. He had an athletic appearance. No frontal boldness was observed. A general stiffness was present in all his muscles. No atrophy or muscle weakness was present. Deep tendon reflexes were normal. Action myotonia was determined in his hands and eyes, and percussion myotonia was determined in his thenar muscles. During the action myotonia examination, the patient could easily make the first fist, whereas he had difficulty in re-opening his hand, and could not form the next fist. He had difficulty in starting the first movement from the sitting position, but once he started walking, the movements became easier. Other systemic examinations were normal. He had no history of a systemic disorder. No intermarriage was present between his mother and father. Similar complaints were present in his father and brother. The other brother and three sisters were alive and healthy. The laboratory findings; complete blood count, serum electrolytes, liver and kidney function tests were normal. The level of lactate dehydrogenase was normal, and creatinine kinase was $906 \mathrm{U} / \mathrm{L}$ (normal levels: 1-171 U/L). The fasting insulin level was 3.74 $\mathrm{mU} / \mathrm{ml}$ and fasting blood glucose level was 85 $\mathrm{mg} / \mathrm{dL}$. No insulin resistance was detected. Telecardiography, electrocardiography and echocardiography findings were normal. His bone densitometric findings were normal. The nerve conduction studies (EMG) was normal. Needle EMG examination showed myotonic discharges in all the muscles. As similar complaints were obvious in his father and brother, a family tree was formed (Figure 1). According to the clinical findings, EMG report and the family tree structure, the disorder was diagnosed as Thomsen's type myotonia congenita. The patient was enrolled in a physical rehabilitation program.

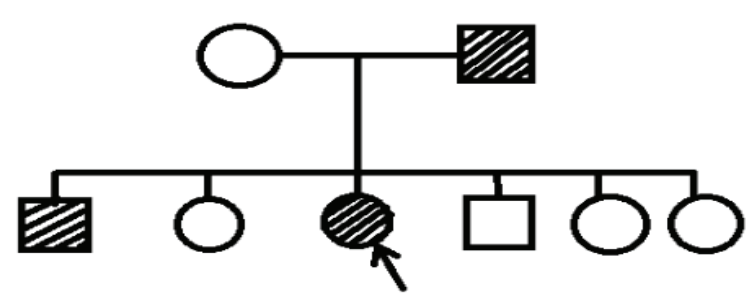

Figure 1. Family tree.

\section{Discussion}

Myotonia congenita is a hereditary disease of ion channels of the skeletal muscle and is characterized by the over-excitability of the membrane of the skeletal muscle. Patients have muscle stiffness and difficulties in starting voluntary activities like walking or running [1]. A characteristic feature of the patients is generalized muscle hypertrophy leading to "Hercules-like" appearance [5]. This hypertrophy is usually developed in the lower extremities because of the continuous contraction of the quadriceps and the other muscles [6].

The most important disorder that should be differentiated from myotonia congenita is myotonic dystrophy. Myotonia is more apparent in myotonia congenita, whereas it is less obvious in myotonic dystrophy. There is weakness in the oculobulbar, cervical and distal extremity muscles in myotonic dystrophy, and there is a typical facial appearance with frontal alopecia and temporal atrophy. Extra-muscular organ involvement may be present including cataracts, hypogonadism, insulin resistance, cardiomyopathy and mental retardation $[7,8]$. Our patient did not have the typical facial appearance observed in myotonic dystrophy and had no extra-muscular organ involvement. Nevertheless, the patient with significant myotonia should be differentiated from myotonic dystrophy.

In "paramyotonia congenita", muscle stiffness is accompanied by muscle weakness, and worsens with movement (paradoxic myotonia) and cold. In "chondrodystrophic 
myotonia" (Schwartz Jampel's syndrome), typical dysmorphic facial appearance, dwarfism and limitations in joint movements are present [1]. In hypercalemic periodic paralysis, hyperkalemia is found during myotonia [2]. Our patient was differentiated from these disorders by not being triggered by the cold, and absence of hypertrophy in his muscles, the typical facial appearance, fluctuations in myotonia or hyperkalemia.

Thomsen's type myotonia congenita (autosomal dominant) is formed in the infantile period. On the contrary, Becker's type (autosomal recessive) myotonia has an onset during childhood (between ages 4 and 12). It is mainly observed in males. Myotonia is first discovered in the legs, a few years later in the arms and hands, then in the neck and face. In other words it shows an ascending progression. Myotonia is commonly significant. The first symptoms in our patient had been observed at 4 or 5 years of age. An ascending progression could not been identified.

Generally a specific phenomenon called "short-term disability" is observed in Becker's type myotonia. According to which; the first contraction during alternating movements is normal however, the strength of muscle contraction suddenly decreases during the following movements. The weakness lasts for a few more contractions, and then it progressively improves and turns to normal. The patients express this feeling generally as a sudden release in the hands during a holding action and a subsequent dropping of the objects [2]. The patient was admitted to our outpatient clinic with the complaint of dropping objects from his hand, and the disorder was diagnosed as shortterm disability phenomenon. It is known that in contrast to the classical knowledge, Thomsen's type may also include the short-term disability phenomenon and other clinical properties (onset during childhood, ascending progression, severe myotonia) [2].

Both the dominant and the recessive forms of the disease include mutations in CLCN1 gene of the $7^{\text {th }}$ chromosome (7q35). This gene encodes the skeletal muscle chlorine channels. It has been suggested that the differences between the two types are related to the different mutations on the same gene and that the diseases are allelic. Usually a mutation cannot be observed in families carrying the dominant type $[2,9]$. We postulated that the patient had Thomsen's type considering the presence of similar diseases in his father and brother, and the absence of intermarriage between his father and mother.

The treatment of myotonia is based on electrically stabilization of the muscle membrane [3]. No treatment is necessary in mild myotonia. Mexiletine is the main drug of choice. Carbamazepine and phenytoin are other treatment options as well. In a study, carbamazepine was effective in a patient with CLCN1 mutation; decrease in muscle stiffness and increase in muscle strength were observed [10]. No medical treatment was administered to our patient since myotonia was not severe. The patient was taken into a physiotherapy program.

In conclusion, we aimed to point out that although the short-term disability phenomenon is usually seen in the presence of Becker's type myotonia congenita, it may rarely be observed in Thomsen's type as well.

Disclosure or Disclaimer: The authors declare no potential conflicts of interest.

\section{References}

1. Lossin C, George AL. Myotonia congenita. Adv Genet 2008;63:25-55.

2. Serdaroğlu-Oflazer P, Deymeer F. Kas ve Nöromusküler Kavşak Hastalıkları. İn: Öge AE, Baykan B, eds. Nöroloji, 2th edition. İstanbul: Nobel Matbaacılık, 2011;729-770.

3. Victor M, Ropper AH. The Hereditary myotonias and periodic paralyses (The Channelopathies). In: Victor M, Ropper AH, eds. Adams and Victor's Principles of Neurology, 7th edition. USA: McGraw Hill (Medical publishing division), 2001;1553-1564.

4. Morales F, Cuance P, del Valle G, et al. Clinical and molecular diagnosis of a Costa Rican family with autosomal recessive myotonia congenita (Becker disease) carrying a new mutation in the CLCN1 gene. Rev Biol Trop 2008;56:1-11.

5. Sheela SR. Myotonia Congenita: Response to Carbamazepine. Indian Pediatrics 2000;37:1122-1125.

6. Bhattacharya KB, Sengupta $P$, Basu $S$, Bhattacharya NP. Becker's variant of myotonia congenita in two siblings-A clinicogenetic study. Neurology India 2004;52:363-364.

7. Moxley III RT, Tawil, Thornton CA. Channelopathies: Myotonic disorders and Periodic paralysis. In: Swaiman KF, Ashwal S, eds. Pediatric Neurology: Principles and Practice. 3rd ed. Mosbs. Missouri, 1999;1299-1310.

8. Schneider C, Reiners K, Toyka KV. Myotonic dystrophy (DM/Curschmann-Steinert disease) and proximal myotonic myopathy (PROMM/Ricker syndrome). Myotonic muscle diseases with multisystemic manifestations. Nervenarzt 2001;72:618-624. 
9. Gurgel-Giannetti J, Senkevics AS, Zilbersztajn-Gotlieb $D$, et al. Thomsen or Becker myotonia? A novel autosomal recessive nonsense mutation in the CLCN1 gene associated with a mild phenotype. Muscle Nerve 2012;45:279-283.
10. Lyons MJ, Duron R, Molinero I, Sangiuolo F, Holden KR. Novel CLCN1 mutation in carbamazepine-responsive myotonia congenita. Pediatr Neurol 2010;42:365-368. 